\title{
/RNA-RELATED TOOLS
}

\begin{tabular}{|c|c|c|c|}
\hline 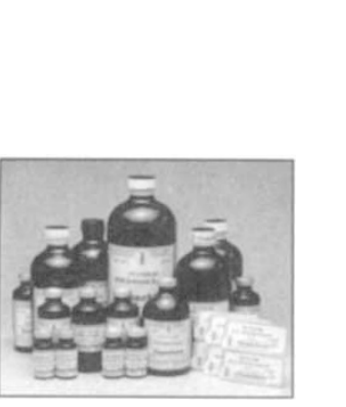 & $\begin{array}{l}\text { RNA synthesis } \\
\text { Cruachem (Glasgow, U.K.) offers } \\
\text { isomerically pure 2'-O-Fpmp-protect- } \\
\text { ed phosphoramidites. Fpmp groups are } \\
\text { stable under ammonolytic conditions } \\
\text { used to cleave synthetic RNA from } \\
\text { CPG. 2'-O-Fpmp RNA is stable to } \\
\text { alkali and endonucleases and can be } \\
\text { purified by HPLC and stored under } \\
\text { nonsterile conditions. } \\
\text { Write in } 923 \text { on Reader Service } \text { Card. }\end{array}$ & $\begin{array}{l}\text { RNA extraction } \\
\text { Ultraspec-3 from Biogenesis (Poole, } \\
\text { U.K.) is a new extraction reagent de- } \\
\text { signed for the extraction of undegraded } \\
\text { and pure RNA from serum and other } \\
\text { biological fluids. The procedure elim- } \\
\text { inates ultracentrifugation and produc- } \\
\text { es RNA suitable for Northern blotting, } \\
\text { dot blotting, RT-PCR, RNA protec- } \\
\text { tion assay, and molecular cloning. } \\
\text { Write in } 924 \text { on Reader Service Card. }\end{array}$ & \\
\hline IIII Invitrogen & $\begin{array}{l}\text { mRNA for cDNA } \\
\text { The FastTrack mRNA isolation kit } \\
\text { from Invitrogen (Leek, the Nether- } \\
\text { lands) allows users to isolate intact, } \\
\text { heterogeneous mRNA for cDNA li- } \\
\text { brary construction. The FastTrack kit } \\
\text { comes complete with a proprietary } \\
\text { RNase/Protein Degrader and RNase- } \\
\text { free solutions and tubes. } \\
\text { Write in } 925 \text { on Reader Service Card. }\end{array}$ & $\begin{array}{l}\text { mRNA isolation } \\
\text { Dynabeads Oligo }(\mathrm{dT})_{25} \text { from Dynal } \\
\text { (Lake Success, NY) isolates pure } \\
\text { mRNA directly from cells, solid tis- } \\
\text { sues, and total RNA in } 15 \text { minutes. } \\
\text { Poly }(\mathrm{A})^{+} \text {RNA is isolated using an } \\
\text { oligo(dT) }{ }_{25} \text { probe covalently bound to } \\
\text { monodisperse superparamagnetic } \\
\text { beads. The reagent may be purchased } \\
\text { alone or as part of a kit. } \\
\text { Write in } 921 \text { on Reader Service Card. }\end{array}$ & $z$ \\
\hline 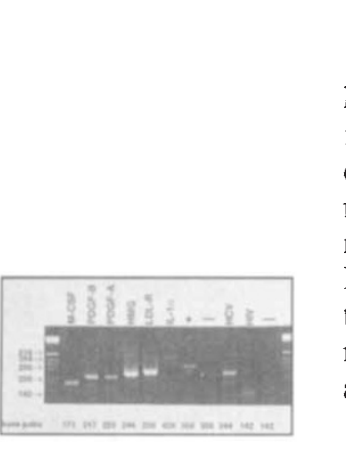 & $\begin{array}{l}\text { PCR kit } \\
\text { The GeneAmp EZ rTth RNA PCR } \\
\text { kit from Perkin-Elmer (Norwalk, CT) } \\
\text { is designed for rapid, sensitive, and } \\
\text { easy sample screening using both the } \\
\text { reverse transcriptase and DNA poly- } \\
\text { merase activities of the thermostable } \\
\text { DNA polymerase rTth. The kit con- } \\
\text { tains all the components required for } \\
\text { reverse transcription of RNA tocDNA } \\
\text { and subsequent amplification. } \\
\text { Write in } 922 \text { on Reader Service Card. }\end{array}$ & $\begin{array}{l}\text { Isolation kit } \\
\text { mRNA isolation kits from Sigma } \\
\text { (St. Louis, MO) allow for isolation of } \\
\text { poly }(\mathrm{A})^{+} \text {RNA directly from cells or } \\
\text { tissues in } 1-2 \text { hours. Treated cells or } \\
\text { tissues are applied directly tooligo(dT)- } \\
\text { cellulose; mRNA is eluted after re- } \\
\text { moval of debris and soluble contami- } \\
\text { nants. } \\
\text { Write in } 920 \text { on Reader Service Card. }\end{array}$ & $\notin$ \\
\hline $\begin{array}{c}\text { INTERNATIONAL ADVERTISING } \\
\text { MANAGER (NEW YORK) } \\
\text { Sande Giaccone 1 (800) 989-1112 } \\
\text { INTERNATIONAL ADVERTISINC } \\
\text { MANAGER (LONDON) } \\
\text { Kathryn Wayman (71) 872-0103 }\end{array}$ & $\begin{array}{c}\text { CANADA } \\
\text { Peter Drake 1 (416) 690-2423 } \\
\text { 17 Pine Crescent } \\
\text { Toronto, Ontario M4E } 11.1 \\
\text { FAX: 1 } \\
\text { (416) 868-1213 }\end{array}$ & $\begin{array}{l}\text { SCANDINAVIA } \\
\text { Andrew Karnig (8) 644400-05 } \\
\text { Andrew Karnig \& Associates } \\
\text { Finnbodavagen I } \\
\text { 13131 NACKA Sweden } \\
\text { FAX: (8) 6-42-31-50 }\end{array}$ & $\begin{array}{l}\text { JAPAN } \\
\text { Phillip Hamill (3) } 267-8751 \\
\text { Shin-Mitsuke Building (4F) } \\
\text { 3-6 Ichigaya Tamachi } \\
\text { Shinjuku-ku Tokog } 162 \\
\text { FAX: (3) 267-8746 }\end{array}$ \\
\hline $\begin{array}{l}\text { EAST COAST \& MIDWEST } \\
\text { Kevin J. Carney } 1(212) 477-3626 \\
65 \text { Bleecker Street } \\
\text { New York, NY 10012 } \\
1 \text { ( } 800) 989-1112 \\
\text { FAX: } 1 \text { (212) } 505-1364\end{array}$ & $\begin{array}{l}\text { UNITED KINGDOM } \\
\text { Kathryn Wayman } \\
\text { Helen Beasley } \\
\text { (71) 872-19103 } \\
\text { 4 Litlele Essex Stree! } \\
\text { London, WC2R SLF } \\
\text { FAX: (71) 240.2408 }\end{array}$ & $\begin{array}{c}\text { FRANCE \& } \\
\text { HOLLAND \& } \\
\text { BELGIUM } \\
\text { Patricia Hummel (1) 43-87-42-17 } \\
5 \text { Rue Joseph Sansboeuf } \\
\text { 75008 Paris France } \\
\text { FAX: (1) 43-87-42-15 }\end{array}$ & $\begin{array}{c}\text { AUSTRALIA } \\
\text { Anne Murrey (2) 299-5677 } \\
\text { World Mcdia Network Pty, Level } 1 \\
\text { 89 York Street, Sydney NSW } 2000 \\
\text { FAX: (2) 299-6178 } \\
\text { ISRAEL }\end{array}$ \\
\hline $\begin{array}{c}\text { WEST COAST \& SOUTHWEST } \\
\text { Jeanette Sims } 1 \text { (415) 781-64422 } \\
582 \text { Market Street, Ste. } 1407 \\
\text { San Francisco, CA 94104 } \\
\text { ( } 800) \text { 2029-9758 } \\
\text { FAX: } 1(415) 781-3805\end{array}$ & $\begin{array}{l}\text { GERMANY \& AUSTRIA } \\
\text { Sabine Fürst (89) } 52-4(1)-81 \\
\text { Sandstrasse } 41 \text {. } \\
\text { D80335. Muinchen } \\
\text { FAX: (89) 523-22-22 }\end{array}$ & $\begin{array}{l}\text { SWITZERLAND } \\
\text { Verena Loewenthal-Hugi (1) } 750-55-11 \\
\text { Interpress Postfach } \\
\text { CH-8103 Unterengstringen } \\
\text { FAX: (1) } 750-22-10\end{array}$ & $\begin{array}{l}\text { Heiko Sieger, Intermedia } \\
\text { (3) 528-7815 } \\
76 \text { King George St. } \\
\text { PO Box 11820 } \\
\text { Tel Aviv, Israel 61116 } \\
\text { FAX: (3) } 299259\end{array}$ \\
\hline
\end{tabular}

